\title{
An Unusual Association between Familial Mediterranean Fever and IgM Nephropathy
}

\author{
Harun Peru ${ }^{\mathrm{a}} \quad$ Ahmet Midhat Elmaci $^{\mathrm{a}} \quad$ Fatih Akin $^{\mathrm{b}} \quad$ Zuhal Akcoren $^{\mathrm{c}}$ \\ Diclehan Orhan ${ }^{c}$

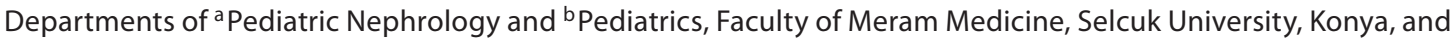 \\ 'Department of Pediatric Pathology, Faculty of Medicine, Hacettepe University, Ankara, Turkey
}

\section{Key Words}

Familial Mediterranean fever - Glomerulonephritis • IgM nephropathy

\begin{abstract}
Objective: To report a case with the diagnosis of IgM nephropathy and familial Mediterranean fever (FMF). Clinical Presentation and Intervention: A 9-year-old boy was admitted to our hospital with recurrent abdominal pain since the age of 4 years. Laboratory investigations revealed a sedimentation rate of $88 \mathrm{~mm} / \mathrm{h}$, C-reactive protein: $83.2 \mathrm{mg} / \mathrm{l}$ (0-10 mg/l), white blood cell count: $12,700 / \mathrm{mm}^{3}$, fibrinogen: $622 \mathrm{mg} / \mathrm{dl}(200-400 \mathrm{mg} / \mathrm{dl})$ and serum amyloid A: $186 \mathrm{mg} / \mathrm{l}$ (0-5.8 mg/l). Urinalysis revealed +2 proteinuria. A 24-hour urinary protein excretion was $12 \mathrm{mg} / \mathrm{m}^{2} / \mathrm{h}$. M694V homozygous mutation was identified in exon 10. Percutaneous renal biopsy showed mesangial cell proliferation and increased mesangial matrix in the glomeruli, without amyloid accumulation. Immunofluorescence study showed IgM (+1) and $\mathrm{C} 1 \mathrm{q}(+1)$ deposits. Treatment with $1 \mathrm{mg} /$ day colchicine was started. Six weeks later, proteinuria had disappeared and the patient was asymptomatic. Conclusion: This case illustrates the unusual association of FMF with non-amyloid glomerulopathy. Glomerular diseases such as IgM nephropathy may be seen as a manifestation of FMF.
\end{abstract}

Copyright $\odot 2008$ S. Karger AG, Base

\section{Introduction}

Familial Mediterranean fever (FMF) is an autosomal recessive disorder characterized by recurrent episodes of fever and polyserositis. It affects primarily people of Mediterranean origin, mostly Sephardic Jews, Armenians, Arabs and Turks $[1,2]$.

The prevalence is $1 / 256$ to $1 / 500$ among non-Ashkenazi Jews, and 1/1,073 among the Turkish population [3, 4]. It is very common in the populations at risk with estimated carrier rates of 1/6 in Armenians, 1/7 in North African Jews, $1 / 13$ in Iraqi Jews and $1 / 5$ in the Arabic population $[3,5,6]$. Cardinal signs and symptoms of FMF are fever, abdominal pain, peritonitis, pleurisy, arthritisarthralgia, erysipelas-like erythema and amyloidosis. Renal amyloidosis is the most severe renal complication of FMF [2]. The association between FMF and non-amyloid glomerulopathy is unusual. We report a case with the diagnosis of IgM nephropathy and FMF in the absence of renal amyloidosis.

\section{Case Report}

A 9-year-old boy was admitted to our hospital with recurrent monthly abdominal pain lasting for 1-2 days since the age of 4 years. He was the only child of non-consanguineous parents and there was no family history for similar symptoms. His height was

\section{KARGER}

Fax +41613061234 E-Mail karger@karger.ch www.karger.com
Dr. Harun Peru

Department of Pediatric Nephrology

Selcuk University, Faculty of Meram Medicine

TR-42080 Meram-Konya (Turkey)

Tel. +90 332223 7430, Fax +90 332223 6181, E-Mail harunperu@gmail.com 


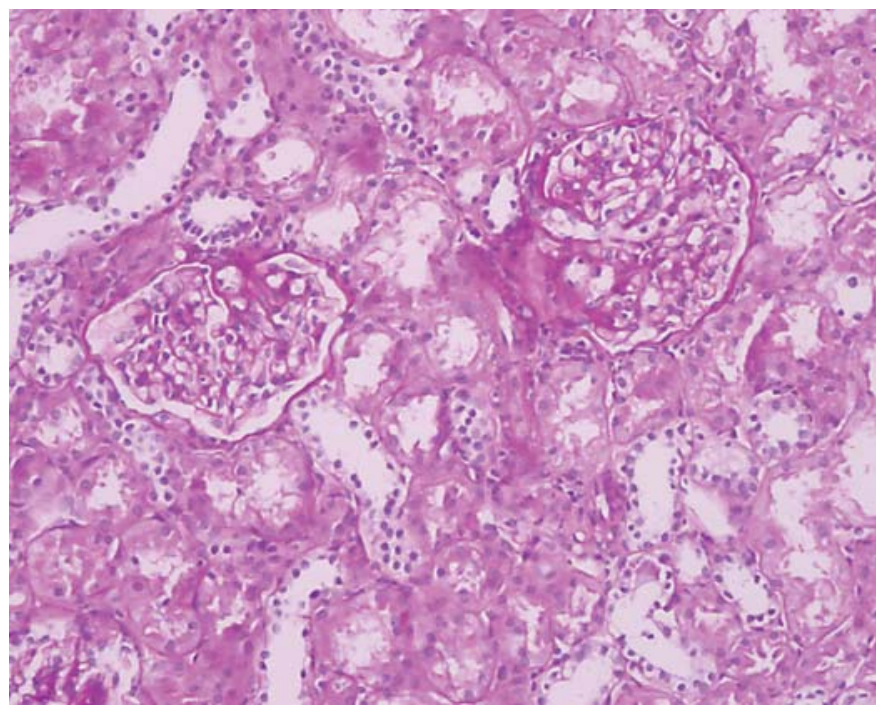

Fig. 1. Minimal mesangial cell proliferation and expansion of the mesangial matrix (PAS, original magnification: $\times 400)$.

$118 \mathrm{~cm}$, which is below the third percentile for his age. Blood pressure and the other physical findings were normal. Laboratory studies showed the following data, hemoglobin: $11.2 \mathrm{~g} / \mathrm{dl}$; platelets; $333,000 / \mathrm{mm}^{3}$, white blood cell count: $12,700 / \mathrm{mm}^{3}$ with $64 \%$ neutrophils, $32 \%$ lymphocytes and $4 \%$ monocytes. The sedimentation rate was $88 \mathrm{~mm} / \mathrm{h}$, C-reactive protein: $83.2 \mathrm{mg} / \mathrm{l}(0-10$ $\mathrm{mg} / \mathrm{l})$; fibrinogen: $622 \mathrm{mg} / \mathrm{dl}(200-400 \mathrm{mg} / \mathrm{dl})$ and serum amyloid A: $186 \mathrm{mg} / \mathrm{l}(0-5.8 \mathrm{mg} / \mathrm{l})$. Urinalysis revealed a $\mathrm{pH}$ of 6 , urine density of 1,020 and +2 proteinuria. 24 -hour urinary protein excretion was $12 \mathrm{mg} / \mathrm{m}^{2} / \mathrm{h}$. Serum BUN, creatinine, albumin, liver function tests, complements $\mathrm{C} 3$ and $\mathrm{C} 4$, antistreptolysin $\mathrm{O}$ and $\mathrm{Ig}$ levels were within normal ranges. Antinuclear antibody and antids-DNA were negative. Renal ultrasonography showed normal size kidneys with grade 1 increase of parenchymal echogenicity.

Percutaneous renal biopsy showed mesangial cell proliferation and expanded glomerular mesangial matrix, without amyloid accumulation (fig. 1). Immunofluorescence study showed IgM (1+) and C1q (1+) deposits. Congo red stain was negative. M694V homozygous mutation was identified in exon 10 confirming the diagnosis of FMF. Treatment with $1 \mathrm{mg} /$ day colchicine was started. After 6 weeks of therapy with colchicines, proteinuria had disappeared and the patient became asymptomatic.

\section{Discussion}

FMF is an autosomal recessive disorder characterized by recurrent episodes of fever and polyserositis. Renal amyloidosis is the most severe complication of FMF resulting in the nephrotic syndrome and eventual renal failure. Mesangioproliferative glomerulonephritis (GN) is the histological finding with expansion of the mesan- gial matrix and mild-to-moderate hypercellularity of the mesangium [7]. Immunofluorescence microscopy shows the IgM deposits.

Previously, IgM and IgA nephropathies, focal and diffuse proliferative GN, mesangiocapillary GN and rapidly progressive GN have been reported in patients with FMF $[8,9]$. Immunological mechanisms play important roles in the pathogenesis of FMF. Immune complexes are noted in $50 \%$ of FMF patients [10]. IgM, IgA and $\mathrm{C}_{3}$ deposits found in the mesangium in our patient and in previously reported cases [10-12] are also supportive of an immunologic mechanism. The occurrence of signs and symptoms of FMF before GN suggests that GN is a result of FMF in our patient, rather than a coincidence. Our patient showed clinical signs of FMF since the age of 4 years, and he had proteinuria at the time of the diagnosis.

Experience regarding the treatment of FMF-related GN is limited, with only few cases being published in the literature $[9,11,12]$; patients were treated with colchicine, prednisolone, cyclophosphamide and azathioprine. Colchicine is the most common agent used to treat FMF-related GN [12]. Said et al. [10] reported significant improvement in 3 patients with IgG nephropathy and FMF, especially with regular treatment with colchicine. Akpolat et al. [11] reported a case treated with prednisolone and azathioprine because of lack of response to colchicine, with persistent proteinuria in non-nephrotic ranges. In a study by Cagdas et al. [12], remission of a patient with FMF and mesangial proliferative GN occurred after 3 years of colchicine treatment alone. Colchicine treatment alone was successful in our patient after 6 weeks of therapy.

\section{Conclusion}

This case illustrates an unusual association between FMF and IgM nephropathy. Glomerular diseases such as IgM nephropathy can be seen as a manifestation of FMF. Although regular colchicine treatment may be effective in treating these patients, further studies addressing the effects of colchicine on disease progression is needed. 


\section{References}

1 Aksentijevich I, Torosyan Y, Samuels J, Centola M, Deng Z, Sood R, Kastner DL: Mutation and haplotype studies of familial Mediterranean fever reveal new ancestral relationships and evidence for a high carrier frequency with reduced penetrance in the Ashkenazi Jewish population. Am J Hum Genet 1999;64:949-962.

-2 Bakkaloglu A: Familial Mediterranean fever. Pediatr Nephrol 2003;18:853-859.

$\checkmark 3$ Daniels M, Shohat T, Brenner-Ullman A, Shohat M: Familial Mediterranean fever: high gene frequency among the non-Ashkenazic and Ashkenazic Jewish populations in Israel. Am J Med Genet 1995;55:311-314.

4 Ozen S, Karaaslan Y, Ozdemir O, Saatci U, Bakkaloglu A, Koroglu E, Tezcan S: Prevalence of juvenile chronic arthritis and familial Mediterranean fever in Turkey: a field study. J Rheumatol 1998;25:2445-2449.
-5 Rogers DB, Shohat M, Petersen GM, Bickal J, Congleton J, Schwabe AD, Rotter JI: Familial Mediterranean fever in Armenians. Autosomal recessive inheritance with high gene frequency. Am J Med Genet 1989;34:168-172.

6 Al-Alami JR, Tayeh MK, Najib DA, AbuRubaiha ZA, Majeed HA, Al-Khateeb MS, El-Shanti HI: Familial Mediterranean fever mutation frequencies and carrier rates among a mixed Arabic population. Saudi Med J 2003;24:1055-1059.

7 Vilches AR, Turner DR, Cameron JS, Ogg CS, Chantler C, Williams DG: Significance of mesangial IgM deposition in 'minimal change' nephrotic syndrome. Lab Invest 1982;46:10-15.

8 Said R, Hamzeh Y, Said S, Tarawneh M, alKhateeb M: Spectrum of renal involvement in familial Mediterranean fever. Kidney Int 1992;41:414-419.
9 Zlotnick A, Levo Y, Fishel R, Ehrenfeld M, Levy M, Shouval D, Eliakin M: Circulating immune complexes in familial Mediterranean fever, systemic lupus erythematosus and HBsAg carriers. Harefuah 1979;97:5557.

10 Said R, Hamzeh Y: IgM nephropathy associated with familial Mediterranean fever. Clin Nephrol 1990;33:227-231.

11 Akpolat T, Akpolat I, Karagoz F, Yilmaz E, Kandemir B, Ozen S: Familial Mediterranean fever and glomerulonephritis and review of literature. Rheumatol Int 2004;24: 43-45.

12 Cagdas DN, Gucer S, Kale G, Duzova A, Ozen S: Familial fever and mesangial proliferative glomerulonephritis: report of a case and review of the literature. Pediatr Nephrol 2005;20:1352-1354. 